\title{
ANALISIS DROP CALL PADA JARINGAN WIDEBAND CODE-DIVISION MULTIPLE ACCESS (WCDMA) DI CLUSTER RENON
}

\author{
I Gusti Ngurah Surya Winata ${ }^{1}$, Gede Sukadarmika ${ }^{2}$, Pande Ketut Sudiarta ${ }^{3}$ \\ ${ }^{1,2,3}$ Program Studi Teknik Elektro, Fakultas Teknik, Universitas Udayana \\ Email: suryajrs@live.com, sukadarmika@unud.ac.id ${ }^{2}$, sudiarta@unud.ac.id ${ }^{3}$
}

\begin{abstract}
Abstrak
Drop call merupakan salah satu contoh permasalahan yang kerap dialami oleh pengguna layanan telekomunikasi suara. Dari permasalahan tersebut maka penelitian ini mengangkat topik mengenai analisis drop call pada jaringan WCDMA di cluster Renon (nodeB MYAMIN_CR, AKABA_PL, dan BUNDARANRENON_PL). Pengambilan data yang dibutuhkan (Call Set Up Success Rate (CSSR), Call Drop Ratio (CDR), RSCP dan Ec/No) dilakukan dengan drive test menggunakan software G-NetTrack Pro. Hasil analisa dari data drive test ditemukan sebanyak 10 kasus drop call. Penyebab drop call ini teridentifikasi akibat missing neighbor, handover failure, bad spot, coverage problem dan overshoot. Dari semua penyebab tersebut, bad spot, coverage problem, dan overshoot merupakan faktor awal dari kasus missing neighbor dan handover failure. Missing neighbor dan handover failure diawali dengan buruknya nilai RSCP dan Ec/No yang diterima sehingga UE akan berusaha melakukan handover. Untuk memperkuat analisa dari hasil drive test maka dilakukan perbandingan data drive test dengan simulasi menggunakan software Atoll. Dari perbandingan tersebut ditemukan adanya kondisi ekstrim akibat dari obstacle yang menyebabkan selisih nilai yang signifikan antara hasil drive test dan simulasi. Tingginya tingkat redaman pada titik terjadinya drop call akibat adanya obstacle juga mengakibatkan nilai RSCP dan Ec/No yang didapat pada saat pengukuran di lapangan menjadi rendah. Rendahnya nilai parameter RSCP dan Ec/No ini kemudian menyebabkan terjadinya drop call.
\end{abstract}

Kata Kunci: Atoll, G-NetTrack Pro, Drop Call, Drive Test

\begin{abstract}
Drop call is an example of a problem that is often experienced by users of voice telecommunications services. From this condition, this riset raises the topic of drop call analysis on WCDMA networks in the Renon cluster (nodeB MYAMIN_CR, AKABA_PL, and BUNDARANRENON_PL). Data retrieval needed (Call Set Up Success Rate (CSSR), Call Drop Ratio (CDR), RSCP and EC/No) is done by drive test using G-NetTrack Pro software. Based on the analysis of the results of the drive test, there were 10 drop call problems. The problems indentified cause by missing neighbors, handover failure, bad spot, coverage problems and overshoot. Bad spots, coverage problems, and overshoot are the initial causes of missing neighbors and handovers failure. Missing neighbors and handover failure begins with the poor value of RSCP and Ec/No, so that the cellphone will try to do a handover. To analyze the drive test results, drive test data is carried out using Atoll software. From the comparison found extreme conditions resulting from obstacle which cause a significant difference in value between the results of the drive test and simulation. The high attenuation rate drop call location due to the obstacle also results in RSCP and Ec/No values being obtained when measurements in the field are low. The low parameter values of RSCP and EC / No then cause a drop call. Keyword: Atoll, G-NetTrack Pro, Drop Call, Drive Test
\end{abstract}

\section{PENDAHULUAN}

Perkembangan telekomunikasi tidak dapat terlepas dari berbagai permasalahan. Beberapa permasalahan sering terjadi pada layanan suara, salah satu contohnya adalah drop call (putusnya koneksi pada saat panggilan sedang berlangsung). Banyak faktor yang menyebabkan terjadinya drop call, diantaranya ada karena gagalnya handover, permasalahan coverage, overshooting, blank spot, dan lainnya.

Penelitian ini mengangkat topik mengenai analisis drop call pada jaringan WCDMA di cluster Renon. Untuk mengambil data yang dibutuhkan dari 
node $B$ yang menjadi objek penelitian (nodeB MYAMIN_CR, AKABA_PL, dan BUNDARANRENON_PL) yaitu berupa data CSSR, CDR, RSCP dan Ec/No dilakukan dengan drive test menggunakan software G-NetTrack Pro. Pada penelitian yang berjudul "Penanganan Block Call dan Drop Call Pada Jaringan UMTS Berdasarkan Pengukuran Parameter Accessibility, Coverage dan Quality" [2], Hasanah Putri menggunakan software TEMS untuk melakukan drive test. Dibandingkan dengan TEMS, G-NetTrack Pro memiliki beberapa keunggulan, terutama dalam hal kemudahan penggunaan, karena tidak memerlukan banyak perangkat. Tetapi GNetTrack Pro juga memiliki kelemahan dibandingkan dengan TEMS, dimana GNetTrack Pro tidak memiliki kemampuan untuk melakukan lock site, sehingga tidak dapat melakukan pengukuran single site verification (SSV) [6].

Dari data yang telah didapat kemudian dilakukan analisis penyebab terjadinya drop call yang diakibatkan oleh parameter RSCP dan Ec/No. Setelah melakukan analisa untuk mengetahui penyebab dari drop call yang terjadi, selanjutnya untuk memperkuat analisa dari hasil drive test maka dilakukan simulasi menggunakan software radio planning Atoll untuk membandingkan kondisi drop call yang terjadi dengan hasil simulasi.

\section{KAJIAN PUSTAKA}

\subsection{Jaringan Seluler}

Seluler merupakan sistem komunikasi yang memberikan layanan komunikasi data, voice, dan video yang dapat dilakukan dalam keadaan bergerak [2].

\subsection{Drop Call}

Drop call adalah kegagalan panggilan yang terjadi setelah panggilan berhasil dilakukan namun berakhir tanpa pemutusan secara normal [4]. Parameter drop call yang digunakan pada penelitian ini adalah:

1) RSCP (Received Signal Code Power)

Merupakan tingkatan sinyal pada jaringan 3G UMTS. RSCP akan mempengaruhi peresentase keberhasilan mengakses layanan telekomunikasi. Nilai parameter yang digunakan untuk parameter RSCP dapat dilihat pada Tabel 1.

Tabel 1. Nilai Parameter RSCP G-NetTrack Pro [5]

\begin{tabular}{|c|c|c|}
\hline Warna & Nilai RSCP (dBm) & Keterangan \\
\hline & $\geq-70$ & Luar Biasa \\
\hline & $-70 \mathrm{~s} / \mathrm{d}-80$ & Sangat Baik \\
\hline & $-80 \mathrm{~s} / \mathrm{d}-90$ & Baik \\
\hline
\end{tabular}

\begin{tabular}{|c|c|c|}
\hline & $-90 \mathrm{~s} / \mathrm{d}-100$ & Normal \\
\hline & $-100 \mathrm{~s} / \mathrm{d}-110$ & Buruk \\
\hline & $<-110$ & Sangat Buruk \\
\hline
\end{tabular}

2) Ec/No (Carrier per Noise)

Merupakan parameter kualitas data/suara pada jaringan 3G. Ec/No akan mempengaruhi presentase kualitas layanan. Nilai parameter yang digunakan untuk parameter Ec/No dapat dilihat pada Tabel 2.

Tabel 2. Nilai Parameter Ec/No G-NetTrack Pro [5]

\begin{tabular}{|c|c|c|}
\hline Warna & Nilai Ec/No (dB) & Keterangan \\
\hline & $\geq 2$ & Luar Biasa \\
\hline & $2 \mathrm{~s} / \mathrm{d}-1$ & Sangat Baik \\
\hline & $-1 \mathrm{~s} / \mathrm{d}-7$ & Baik \\
\hline & $-7 \mathrm{~s} / \mathrm{d}-10$ & Normal \\
\hline & $-10 \mathrm{~s} / \mathrm{d}-14$ & Buruk \\
\hline & $<-14$ & Sangat Buruk \\
\hline
\end{tabular}

3) CSSR (Call Setup Succes Rate)

Merupakan standarisasi peresentase tingkat keberhasilan panggilan oleh ketersediaan kanal suara. Rumus untuk menghitung CSSR adalah sebagai berikut:

CSSR $=\frac{\text { Jumlah Call Attempt }- \text { Block Call }}{\text { Jumlah Call Attempt }} \times 100 \% \ldots$

4) CDR (Call Drop Rate)

CDR merupakan peresentase tingkat kegagalan maupun tingkat gangguan pada proses komunikasi, yang ditandai dengan terputusnya hubungan antara penelepon dan penerima. Rumus untuk menghitung CDR adalah sebagai berikut:

$C D R=\frac{\text { Jumlah Droped Call }}{\text { Jumlah Call Answer }} \times 100 \%$

\subsection{Parameter KPI (Key Performance Indicator) Target}

$\mathrm{KPI}$ target merupakan target performansi jaringan yang harus di peroleh dalam kurun waktu tertentu. Untuk mengetahui kondisi jaringan secara menyeluruh, diperlukan beberapa indikator jaringan yang disebut parameter trafik [1].

Standar KPI Target yang digunakan pada penelitian ini dapat dilihat pada Tabel 3 dibawah.

Tabel 3. Tabel KPI Target Indosat Ooredoo

\begin{tabular}{|c|l|c|}
\hline No & \multicolumn{1}{|c|}{ Indicator } & Target \\
\hline $\mathbf{1}$ & Call Set Up Success Rate & $\geq 90 \%$ \\
\hline $\mathbf{2}$ & Call Drop Ratio & $\leq 0,5 \%$ \\
\hline
\end{tabular}

\subsection{Penyebab Drop Call}

Analisis drop call berguna untuk mengetahui prinsip dasar drop call serta 
penyebab drop call. Drop call dapat terjadi karena beberapa hal antara lain [3]:
a) Coverage Problem
b) Missing Neighbor
c) Handover Failure
d) Overshooting Problem
e) Ping-Pong Handover
f) Propagation Loss
g) Interferensi
h) Zona Mati
i) Bad Spot

\section{METODE PENELITIAN}

\subsection{Alur Penelitian Umum}

Proses dalam menganalisa problem drop call dilakukan dalam beberapa tahapan. Tahapan analisa tersebut dapat dilihat pada Gambar 1 dibawah ini.

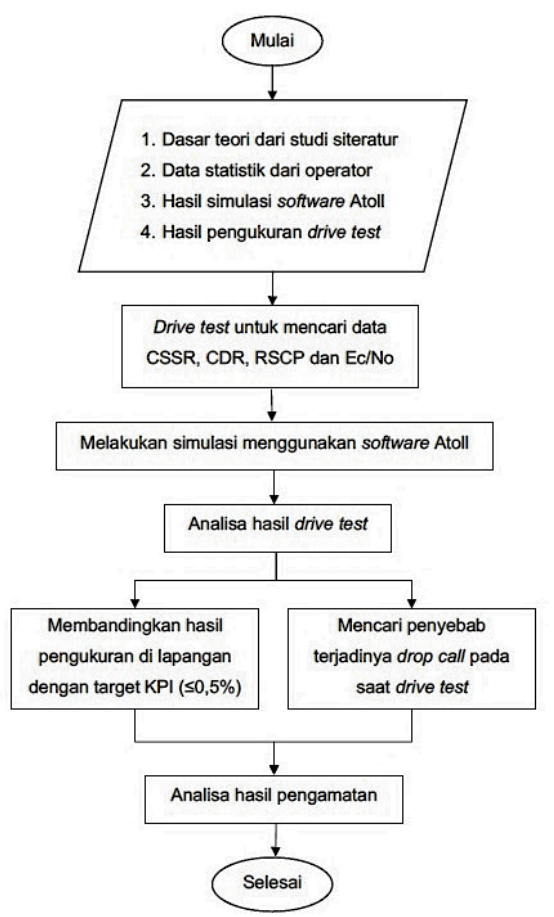

Gambar 1. Alur Penelitian Umum

Berdasarkan diagram Gambar 1, penelitian dimulai dengan melakukan studi literatur yang mencakup penelitian yang akan dilakukan dan mengamati data statistik tentang drop call pada nodeB yang didapat dari operator. Selanjutnya dilakukan drive test untuk mengetahui beberapa parameter KPI berupa CSSR, CDR, RSCP dan Ec/No. Setelah mendapat parameter tersebut maka dilanjutkan dengan proses analisis hasil data drive test yang telah dilakukan. Selanjutkan hasil pengukuran di lapangan dibandingkan dengan standar KPI yang didapat dari operator dan mencari penyebab terjadinya drop call tersebut. Selanjutnya untuk memperkuat analisa dari hasil drive test maka dilakukan simulasi menggunakan software radio planning Atoll untuk membandingkan kondisi drop call yang terjadi dengan hasil simulasi.

\section{HASIL DAN PEMBAHASAN \\ 4.1 Data Drop Call}

Drive test dilakukan dengan pembagian 2 hari libur (Sabtu 7 Juli 2018 \& Minggu 29 Juli 2018) dan 2 hari kerja (Senin \& Selasa, 9 - 10 Juli 2018). Rangkuman data hasil analisis drop call yang telah dilakukan dapat dilihat pada Tabel 4 dibawah ini.

Tabel 4. Data Hasil Analisis Drop Call

\begin{tabular}{|c|c|c|}
\hline $\begin{array}{c}\text { Hari I } \\
\text { Waktu }\end{array}$ & nodeB & Keterangan \\
\hline $\begin{array}{l}\text { Senin, } \\
\text { 9 Juli } \\
\text { 10:44 }\end{array}$ & $\begin{array}{l}\text { MYAMIN_CR } \\
\text { Sektor } 1 \\
(1-2)\end{array}$ & $\begin{array}{l}\text { Disebabkan kegagalan } \\
\text { handover yang diakibatkan } \\
\text { lebih rendahnya nilai RSCP } \\
\text { dan Ec/No dari neighbor } \\
\text { yang akan dituju. }\end{array}$ \\
\hline $\begin{array}{l}\text { Selasa, } \\
10 \text { Juli } \\
17: 31\end{array}$ & $\begin{array}{c}\text { BUNDARANR } \\
\text { ENON_PL } \\
\text { Sektor } 3 \\
(4-1)\end{array}$ & $\begin{array}{l}\text { Disebabkan nilai Ec/No yang } \\
\text { buruk dan missing neighbor } \\
\text { karena tidak adanya } \\
\text { neighbor yang dapat } \\
\text { digunakan untuk melakukan } \\
\text { handover yang di akibatkan } \\
\text { area terjadinya drop call tidak } \\
\text { tercakup oleh cell neighbor } \\
\text { lain. }\end{array}$ \\
\hline $\begin{array}{l}\text { Selasa, } \\
10 \text { Juli } \\
17: 40\end{array}$ & $\begin{array}{l}\text { AKABA_PL } \\
\text { Sektor } 1 \\
(4-2)\end{array}$ & $\begin{array}{l}\text { Disebabkan karena nilai } \\
\text { Ec/No yang buruk dan tidak } \\
\text { adanya neighbor yang } \\
\text { memiliki nilai parameter lebih } \\
\text { baik. }\end{array}$ \\
\hline $\begin{array}{l}\text { Sabtu, } \\
7 \text { Juli } \\
\text { 10:54 }\end{array}$ & $\begin{array}{l}\text { MYAMIN_CR } \\
\text { Sektor } 2 \\
(5-1)\end{array}$ & $\begin{array}{l}\text { Disebabkan karena gagalnya } \\
\text { UE melakukan handover } \\
\text { serta overshoot dari nodeB } \\
\text { MYAMIN_CR, ini ditinjau } \\
\text { berdasarkan daerah yang } \\
\text { dicakup cell tersebut } \\
\text { seharusnya dicakup oleh cell } \\
\text { yang letaknya lebih dekat. }\end{array}$ \\
\hline $\begin{array}{l}\text { Sabtu, } \\
7 \text { Juli } \\
11: 11\end{array}$ & $\begin{array}{l}\text { BUNDARAN } \\
\text { RENON_PL } \\
\text { Sektor } 3 \\
(5-2)\end{array}$ & $\begin{array}{l}\text { Overshoot dari nodeB } \\
\text { BUNDARANRENON_PL dan } \\
\text { missing neighbor, yaitu UE } \\
\text { tidak dapat menemukan } \\
\text { nodeB AKABA_PL yang } \\
\text { berjarak lebih dekat dari } \\
\text { nodeB } \\
\text { BUNDARANRENON PL. }\end{array}$ \\
\hline $\begin{array}{l}\text { Sabtu, } \\
7 \text { Juli } \\
\text { 17:19 }\end{array}$ & $\begin{array}{c}\text { AKABA_PL } \\
\text { Sektor } 3 \\
(6-1)\end{array}$ & $\begin{array}{l}\text { Disebabkan penurunan nilai } \\
\text { RSCP dan Ec/No serta } \\
\text { missing neighbor karena } \\
\text { tidak adanya neighbor yang } \\
\text { dapat digunakan untuk } \\
\text { melakukan handover yang } \\
\text { diakibatkan titik terjadinya } \\
\text { drop call tidak tercakup oleh } \\
\text { cell neighbor. }\end{array}$ \\
\hline $\begin{array}{l}\text { Ming. } \\
29 \text { Juli } \\
\text { 10:05 }\end{array}$ & $\begin{array}{c}\text { AKABA_PL } \\
\text { Sektor } 3 \\
(7-1)\end{array}$ & $\begin{array}{l}\text { Disebabkan kegagalan } \\
\text { handover yang di akibatkan } \\
\text { kesalahan UE dalam } \\
\text { pemilihan neighbor, karena } \\
\text { nilai parameter nodeB yang } \\
\text { dituju tidak lebih dari nodeB } \\
\text { sebelumnya. }\end{array}$ \\
\hline
\end{tabular}




\begin{tabular}{|c|c|c|}
\hline $\begin{array}{l}\text { Ming. } \\
29 \text { Juli } \\
10: 33\end{array}$ & $\begin{array}{c}\text { BUNDARAN } \\
\text { RENON_PL } \\
\text { Sektor } 3 \\
(7-2)\end{array}$ & $\begin{array}{l}\text { Disebabkan karena } \\
\text { kegagalan handover yang di } \\
\text { akibatkan oleh hilangnya } \\
\text { cakupan sinyal dari nodeB } \\
\text { AKABA_PL yang seharusnya } \\
\text { melayani UE, sehingga UE } \\
\text { kembali melakukan handover } \\
\text { ke nodeB } \\
\text { BUNDARANRENON PL. }\end{array}$ \\
\hline $\begin{array}{l}\text { Ming. } \\
29 \text { Juli } \\
17: 37\end{array}$ & $\begin{array}{c}\text { AKABA_PL } \\
\text { Sektor } 2 \\
(8-1)\end{array}$ & $\begin{array}{lr}\text { Disebabkan terjadinya } \\
\text { penurunan RSCP dan Ec/No } \\
\text { serta missing neighbor } \\
\text { karena tidak adanya } \\
\text { neighbor yang dapat } \\
\text { digunakan untuk melakukan } \\
\text { handover yang di akibatkan } \\
\text { titik terjadinya drop call tidak } \\
\text { tercakup oleh cell neighbor. }\end{array}$ \\
\hline
\end{tabular}

Pada Tabel 5 dapat dilihat jenis - jenis permasalahan drop call yang ditemukan selama melakukan penelitian.

Tabel 5. Jenis Permasalahan Drop Call

\begin{tabular}{|c|c|c|}
\hline Jenis & Jml. & Nomor Drop Call \\
\hline Handover Failure & 4 & $1-2 ; 5-1 ; 7-1 ; 7-2$ \\
\hline Missing Neighbor & 4 & $4-1 ; 5-2 ; 6-1 ; 8-1$ \\
\hline Bad Spot & 4 & $4-1 ; 4-2 ; 6-1 ; 8-1$ \\
\hline Coverage Problem & 2 & $6-1 ; 8-1$ \\
\hline Overshoot & 2 & $5-1 ; 5-2$ \\
\hline
\end{tabular}

Berdasakan hasil analisa yang telah dilakukan dapat disimpulkan, semua permasalahan drop call yang terjadi pada saat penelitian sangat dipengaruhi oleh parameter RSCP dan Ec/No.

\subsection{Analisis Hasil Simulasi Kuat Sinyal dilihat dari Parameter RSCP \\ Setelah melakukan kalkulasi} menggunakan Atoll, maka akan muncul hasil prediksi coverage area dari parameter RSCP yang dapat dilihat pada Gambar 2 .

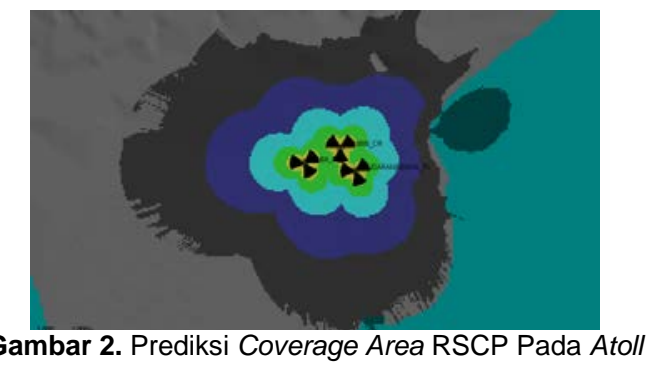

Nilai rata -rata yang didapatkan dari simulasi adalah $-85,87 \mathrm{dBm}$ dengan total cakupan coverage $2,39 \mathrm{~km}^{2}(-90 \mathrm{dBm} \mathrm{s} / \mathrm{d}$ $80 \mathrm{dBm})$. Merujuk pada Tabel 1, nilai tersebut masuk dalam kategori "Baik"

\subsection{Analisis Hasil Simulasi Kuat Sinyal dilihat dari Parameter Ec/No \\ Setelah melakukan kalkulasi menggunakan Atoll, maka akan muncul}

hasil prediksi coverage area dari parameter Ec/No yang dapat dilihat pada Gambar 3.

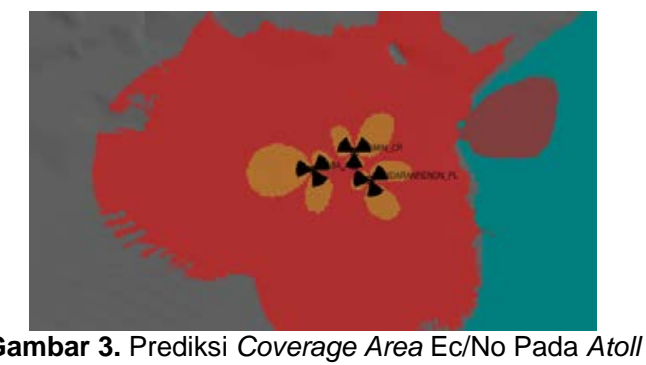

Nilai rata - rata yang didapatkan dari simulasi adalah $-23,56 \mathrm{~dB}$ dengan total cakupan coverage $55,54 \mathrm{~km}^{2}(-14 \mathrm{~dB}$ hingga $-24 \mathrm{~dB}$ ). Merujuk pada Tabel 2, nilai tersebut masuk dalam kategori "Sangat Buruk"

\subsection{Analisis Perbandingan Hasil Pengukuran Drive Test dengan Hasil Simulasi Atoll}

Setelah menganalisis permasalahan drop call yang terjadi, selanjutnya dilakukan perbandingan hasil yang didapat di lapangan dengan hasil yang didapat dari simulasi.

\section{1) Perbandingan Nilai RSCP}

Perbandingan parameter RSCP dari titik - titik drop call yang terjadi antara hasil pengukuran di lapangan dengan hasil simulasi dapat dilihat pada Tabel 6 .

Tabel 6. Hasil Perbandingan RSCP

\begin{tabular}{|c|c|c|c|c|c|}
\hline \multirow{2}{*}{ DC } & \multirow{2}{*}{ node $B$} & \multicolumn{2}{|c|}{ RSCP (dBm) } & \multirow{2}{*}{$\begin{array}{l}\text { Margin } \\
(\mathrm{dBm})\end{array}$} & \multirow{2}{*}{$\begin{array}{c}\text { Jarak } \\
(\mathrm{m})\end{array}$} \\
\hline & & DT & Atoll & & \\
\hline $1-2$ & MYAMIN_CR1 & -85 & $-69,3$ & $-15,7$ & 70 \\
\hline 4-1 & $\begin{array}{l}\text { BUNDARAN } \\
\text { RENON PL3 }\end{array}$ & -103 & $-89,18$ & $-13,82$ & 647 \\
\hline $4-2$ & AKABA_PL1 & -99 & $-91,55$ & $-7,45$ & 616 \\
\hline $5-1$ & MYAMIN_CR2 & $\begin{array}{l}-99 \\
\end{array}$ & $-83,12$ & $-15,88$ & 440 \\
\hline $5-2$ & $\begin{array}{l}\text { BUNDARAN } \\
\text { RENON PL3 }\end{array}$ & -95 & $-97,49$ & $-2,49$ & 1022 \\
\hline $6-1$ & AKABA_PL3 & -95 & $-78,74$ & $-16,26$ & 376 \\
\hline $7-1$ & AKABA PL3 & -103 & $-88,05$ & $-14,95$ & 603 \\
\hline $7-2$ & $\begin{array}{l}\text { BUNDARAN } \\
\text { RENON PL3 }\end{array}$ & -105 & $-92,37$ & $-12,63$ & 759 \\
\hline 8-1 & AKABA_PL2 & $\begin{array}{l}-103 \\
\end{array}$ & $-83,49$ & $-19,51$ & 475 \\
\hline
\end{tabular}

Dari Tabel 6 di atas dapat dilihat adanya perbedaan nilai parameter antara hasil pengukuran di lapangan dengan hasil simulasi. Untuk memperkecil selisih nilai dari parameter RSCP ini dapat dilakukan dengan menggunakan faktor koreksi dari rata - rata selisih nilai yang didapat. Faktor koreksi pada kondisi khusus (warna kuning) adalah -2,49 dBm, dan -14,5 dBm untuk kondisi normal.

\section{2) Perbandingan Nilai Ec/No}


Perbandingan parameter Ec/No dari titik - titik drop call yang terjadi antara hasil pengukuran di lapangan dengan hasil simulasi dapat dilihat pada Tabel 7.

Tabel 7. Hasil Perbandingan Ec/No

\begin{tabular}{|c|c|c|c|c|c|}
\hline \multirow[b]{2}{*}{ DC } & \multirow{2}{*}{ nodeB } & \multicolumn{2}{|c|}{ Ec/No (dB) } & \multirow[b]{2}{*}{ Margin } & \multirow{2}{*}{$\begin{array}{c}\text { Jarak } \\
(\mathrm{m})\end{array}$} \\
\hline & & DT & Atoll & & \\
\hline $1-2$ & MYAMIN_CR1 & -14 & $-13,04$ & $-0,96$ & 70 \\
\hline 4-1 & $\begin{array}{l}\text { BUNDARAN } \\
\text { RENON PL3 }\end{array}$ & -18 & $-16,6$ & $-1,4$ & 647 \\
\hline $4-2$ & AKABA PL1 & -19 & $-18,3$ & $-0,7$ & 616 \\
\hline $5-1$ & MYAMIN_CR2 & -18 & $-16,23$ & $-1,77$ & 440 \\
\hline $5-2$ & $\begin{array}{l}\text { BUNDARAN } \\
\text { RENON_PL3 }\end{array}$ & -17 & $-28,07$ & $-11,07$ & 1022 \\
\hline $6-1$ & AKABA PL3 & -16 & $-13,02$ & $-2,98$ & 376 \\
\hline $7-1$ & AKABA_PL3 & -19 & $-13,08$ & $-5,92$ & 603 \\
\hline $7-2$ & $\begin{array}{l}\text { BUNDARAN } \\
\text { RENON_PL3 }\end{array}$ & -20 & $-16,9$ & $-3,1$ & 759 \\
\hline $8-1$ & AKABA PL2 & -17 & -13.35 & $-3,65$ & 475 \\
\hline
\end{tabular}

Dari Tabel 7 di atas dapat dilihat adanya perbedaan nilai parameter antara hasil pengukuran di lapangan dengan hasil simulasi. Untuk memperkecil selisih nilai dari parameter Ec/No ini dapat dilakukan dengan menggunakan faktor koreksi dari rata - rata selisih nilai yang didapat. Faktor koreksi pada kondisi khusus (warna kuning) adalah $-11,07 \mathrm{~dB}$, dan -2,56 dB untuk kondisi normal.

\subsection{Analisis Perbandingan Hasil Pengukuran Drive Test dengan Hasil Simulasi Atoll Setelah Menambahkan Faktor Koreksi}

Faktor koreksi digunakan untuk mengganti variabel default formula model propagasi Cost231-Hatta pada software atoll untuk memperkecil margin antara hasil pengukuran di lapangan dengan hasil simulasi.

\section{1) Perbandingan Coverage Area RSCP menggunakan Faktor Koreksi}

Gambar 4 menunjukkan perbandingan coverage area RSCP sebelum dan sesudah memasukan nilai faktor koreksi sebesar $-14,5 \mathrm{dBm}$ dan $-2,49 \mathrm{dBm}$

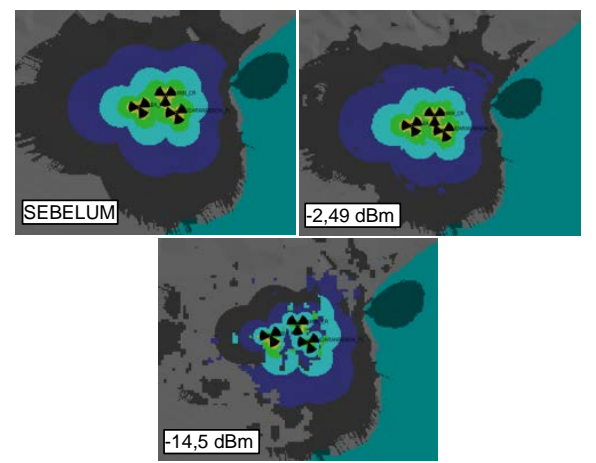

Gambar 4. Perbandingan Coverage Area Parameter RSCP
Untuk perbandingan lebih lengkap antara nilai parameter RSCP sesudah memasukan nilai faktor koreksi dapat dilihat pada Tabel 8 di bawah.

Tabel 8. Hasil Perbandingan Parameter RSCP Menggunakan Faktor Koreksi

\begin{tabular}{|c|c|c|c|c|c|}
\hline \multirow{2}{*}{ DC } & \multirow{2}{*}{ nodeB } & \multicolumn{2}{|c|}{ RSCP (dBm) } & Margin & Jarak \\
\cline { 3 - 4 } & & DT & Atoll & (dBm) & (m) \\
\hline 1-2 & MYAMIN_CR1 & -85 & $-83,8$ & $-1,2$ & 70 \\
\hline $\mathbf{4 - 1}$ & $\begin{array}{c}\text { BUNDARAN } \\
\text { RENON_PL3 }\end{array}$ & -103 & $-103,6$ & $-0,8$ & 647 \\
\hline $\mathbf{4 - 2}$ & AKABA_PL1 & -99 & -106 & -7 & 616 \\
\hline $\mathbf{5 - 1}$ & MYAMIN_CR2 & -99 & $-97,62$ & $-1,38$ & 440 \\
\hline $\mathbf{5 - 2}$ & $\begin{array}{c}\text { BUNDARAN } \\
\text { RENON_PL3 }\end{array}$ & -95 & $-94,99$ & $-0,1$ & 1022 \\
\hline $\mathbf{6 - 1}$ & AKABA_PL3 & -95 & $-78,74$ & $-16,26$ & 376 \\
\hline $\mathbf{7 - 1}$ & AKABA_PL3 & -103 & $-102,5$ & $-0,5$ & 603 \\
\hline $\mathbf{7 - 2}$ & $\begin{array}{c}\text { BUNDARAN } \\
\text { RENON_PL3 }\end{array}$ & -105 & $-106,8$ & $-1,8$ & 759 \\
\hline $\mathbf{8 - 1}$ & AKABA_PL2 & -103 & $-97,99$ & $-5,01$ & 475 \\
\hline \multicolumn{7}{|c|}{ Terdapat } \\
\hline
\end{tabular}

Terdapat 1 kondisi khusus yang dikarenakan nilai simulasi lebih rendah dibandingkan nilai pengukuran (warna kuning) dan 1 kondisi ekstrim yang dikarenakan selisih nilai yang didapat mencapai 16,26 dBm (warna merah) sehingga masih diperlukan analisa lebih lanjut.

a) Analisa Titik Drop Call 5-2

Titik drop call 5-2 yang ditampilkan menggunakan Atoll dapat dilihat pada Gambar 5 di bawah ini.

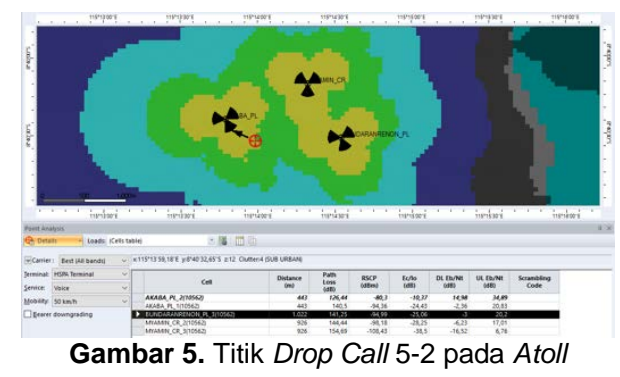

Sebelum menambahkan faktor koreksi, simulasi menunjukan nilai yang lebih rendah $(-97,49 \mathrm{dBm})$ dibandingkan hasil pengukuran di lapangan (-95 dBm) dengan margin -2,49 dBm. Sedangkan setelah menambahkan faktor koreksi sebesar -2,49 $\mathrm{dBm}$, nilai pada simulasi menjadi lebih baik $(-94,99 \mathrm{dBm})$ dan mendekati nilai pengukuran di lapangan (-95 dBm).

Perbedaan nilai pada simulasi sebelum menggunakan faktor koreksi dapat diakibatkan oleh beberapa hal yang terjadi pada transmitter, media transmisi dan user equipment.

b) Analisa Titik Drop Call 6-1

Titik drop call 6-1 yang ditampilkan menggunakan Atoll dapat dilihat pada Gambar 6 di bawah ini. 


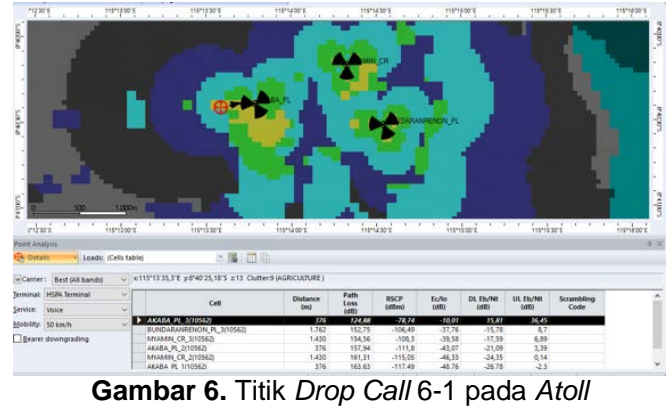

Pada titik ini tidak ada perubahan sebelum dan sesudah menambahkan nilai faktor koreksi. Pengukuran di lapangan menunjukan nilai yang lebih rendah (-95 $\mathrm{dBm})$ dibandingkan hasil simulasi menggunakan Atoll $(-78,74 \mathrm{dBm})$ dengan selisih nilai $-16,26 \mathrm{dBm}$. Walaupun secara simulasi tergolong baik, tetapi pada kenyataannya tetap terjadi drop call pada titik tersebut pada saat pengukuran di lapangan.

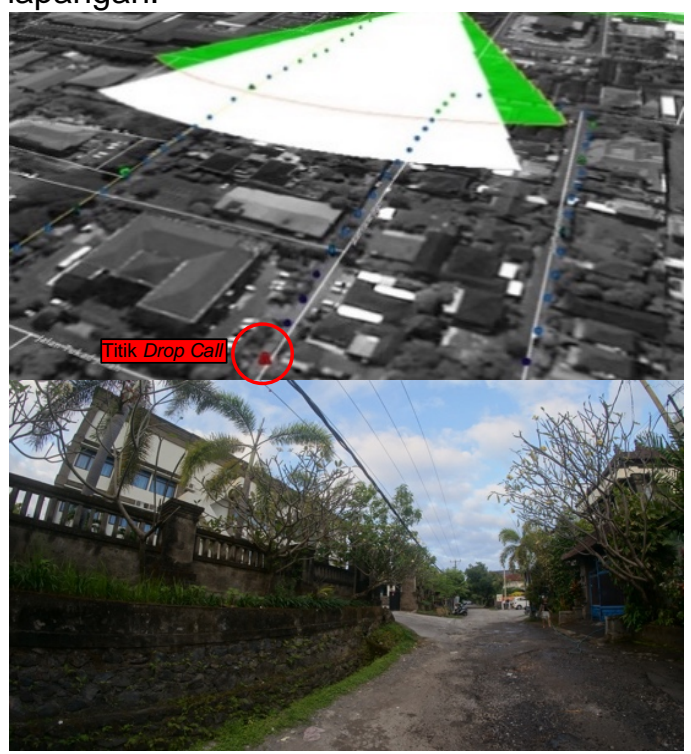

Gambar 7. Kondisi Real Titik Drop Call 6-1

Gambar 7 menunjukkan adanya obstacle berupa gedung dengan tinggi $\pm 15 \mathrm{~m}$. Adanya obstacle ini menyebabkan margin yang didapat menjadi besar. Ini dapat dibuktikan dimana nilai yang didapat sebelum obstacle lebih baik $(-95 \mathrm{dBm})$ dari pada nilai di titik terjadinya drop call (-101 $\mathrm{dBm})$. Selain itu, jika dilihat dari simulasi, nilai yang didapat sebelum titik drop call ($76,42 \mathrm{dBm}$ ) juga lebih baik dibandingkan nilai pada titik drop call $(-76,78 \mathrm{dBm})$. Seperti yang dapat dilihat pada Tabel 9 berikut:

Tabel 9. Perbandingan Titik Drop Call 6-1

\begin{tabular}{|c|c|c|c|}
\hline Koordinat & Keterangan & $\begin{array}{c}\text { Atoll } \\
(\mathrm{dBm})\end{array}$ & $\begin{array}{c}\text { Pengukuran } \\
(\mathrm{dBm})\end{array}$ \\
\hline
\end{tabular}

\begin{tabular}{|c|c|c|c|}
\hline $\begin{array}{c}8^{\circ} 40^{\prime} 25.19^{\prime \prime S} \\
115^{\circ} 13^{\prime} 35.29 " \mathrm{E}\end{array}$ & Titik Drop Call & $-78,74$ & -101 \\
\hline $\begin{array}{c}8^{\circ} 40^{\prime} 25.15^{\prime \prime S} \\
115^{\circ} 13^{\prime} 36.86 " \mathrm{E}\end{array}$ & $\begin{array}{l}\text { Sebelum Titik } \\
\text { Drop Call }\end{array}$ & $-76,42$ & -95 \\
\hline
\end{tabular}

Dengan demikian, kondisi ekstrim ini disebabkan karena adanya obstacle tersebut pada kondisi real di lapangan, sehingga nilai RSCP yang didapat pada pengukuran memiliki selisih yang signifikan dibandingkan nilai pada simulasi.

\section{2) Perbandingan Coverage Area Ec/No menggunakan Faktor Koreksi}

Gambar 8 menunjukkan perbandingan coverage area Ec/No sebelum dan sesudah memasukan nilai faktor koreksi sebesar 2,56 dB dan $-11,07 \mathrm{~dB}$.

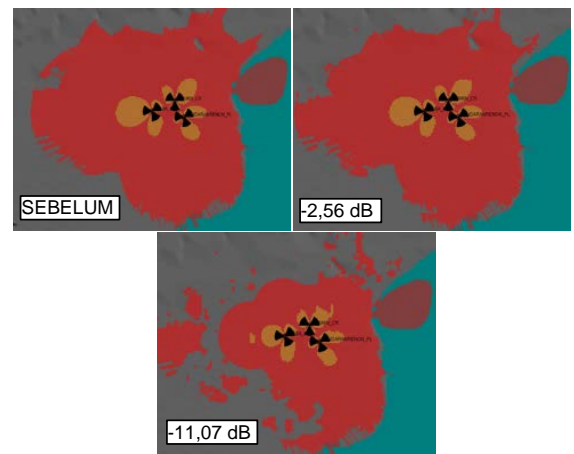

Gambar 8. Perbandingan Coverage Area Parameter Ec/No

Untuk perbandingan lebih lengkap dapat dilihat pada Tabel 10 di bawah.

Tabel 10. Hasil Perbandingan Parameter Ec/No Menggunakan Faktor Koreksi

\begin{tabular}{|c|c|c|c|c|c|}
\hline \multirow{2}{*}{ DC } & \multirow{2}{*}{ nodeB } & \multicolumn{2}{|c|}{ Ec/No (dB) } & \multirow{2}{*}{ Margin } & \multirow{2}{*}{$\begin{array}{c}\text { Jarak } \\
(\mathrm{m})\end{array}$} \\
\hline & & DT & Atoll & & \\
\hline $1-2$ & MYAMIN_CR1 & -14 & $-13,04$ & $-0,96$ & 70 \\
\hline $4-1$ & $\begin{array}{l}\text { BUNDARAN } \\
\text { RENON PL3 }\end{array}$ & -18 & $-16,6$ & $-1,4$ & 647 \\
\hline $4-2$ & AKABA_PL1 & -19 & $-18,3$ & $-0,7$ & 616 \\
\hline $5-1$ & MYAMIN_CR2 & -18 & $-16,23$ & $-1,77$ & 440 \\
\hline $5-2$ & $\begin{array}{l}\text { BUNDARAN } \\
\text { RENON_PL3 }\end{array}$ & -17 & $-28,12$ & -11.12 & 1022 \\
\hline $6-1$ & AKABA_PL3 & -16 & $-13,02$ & $-2,98$ & 376 \\
\hline $7-1$ & AKABA_PL3 & -19 & -13.09 & $-5,91$ & 633 \\
\hline $7-2$ & $\begin{array}{l}\text { BUNDARAN } \\
\text { RENON_PL3 }\end{array}$ & -20 & $-16,92$ & $-3,08$ & 759 \\
\hline $8-1$ & AKABA_PL2 & -17 & $-13,35$ & $-3,65$ & 475 \\
\hline
\end{tabular}

Terdapat 1 kondisi khusus yang dikarenakan nilai simulasi lebih rendah dibandingkan nilai pengukuran (warna kuning) dan 1 kondisi ekstrim dimana nilai selisih hampir mencapai $6 \mathrm{~dB}$ (warna merah) sehingga masih diperlukan analisa lebih lanjut.

\section{a) Analisa Titik Drop Call 5-2}

Titik drop call 5-2 yang ditampilkan menggunakan Atoll dapat dilihat pada Gambar 9 di bawah ini. 


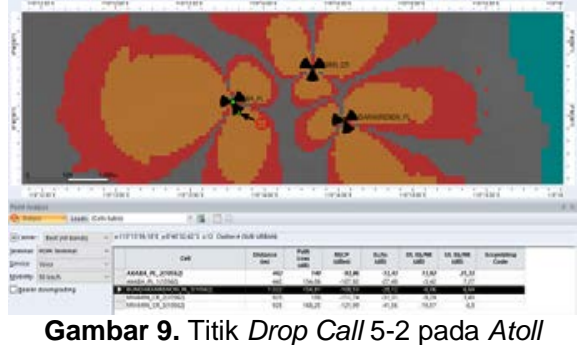

Pada simulasi dapat dilihat, Atoll secara default memilih UE dilayani oleh nodeB AKABA PL karena memiliki nilai Ec/No yang lebih baik dan jarak yang lebih dekat $(443 \mathrm{~m})$, tetapi pada saat pengukuran di lapangan, UE tidak dapat menemukan nodeB AKABA_PL, dan tetap melakukan serving ke BUNDARANRENON_PL.

b) Analisa Titik Drop Call 7-1

Titik drop call 7-1 yang ditampilkan menggunakan Atoll dapat dilihat pada Gambar 10 di bawah ini.

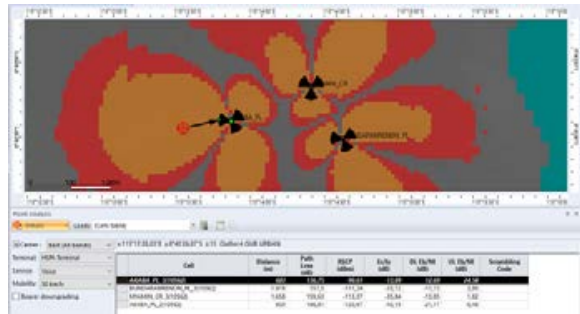

Gambar 10. Titik Drop Call 7-1 pada Atoll

Pengukuran di lapangan menunjukan nilai yang lebih rendah $(-19 \mathrm{~dB})$ dibandingkan hasil simulasi $(-13,09 \mathrm{~dB})$. Walaupun secara simulasi didapat nilai Ec/No lebih baik, tetapi pada kenyataannya tetap terjadi drop call pada titik tersebut.

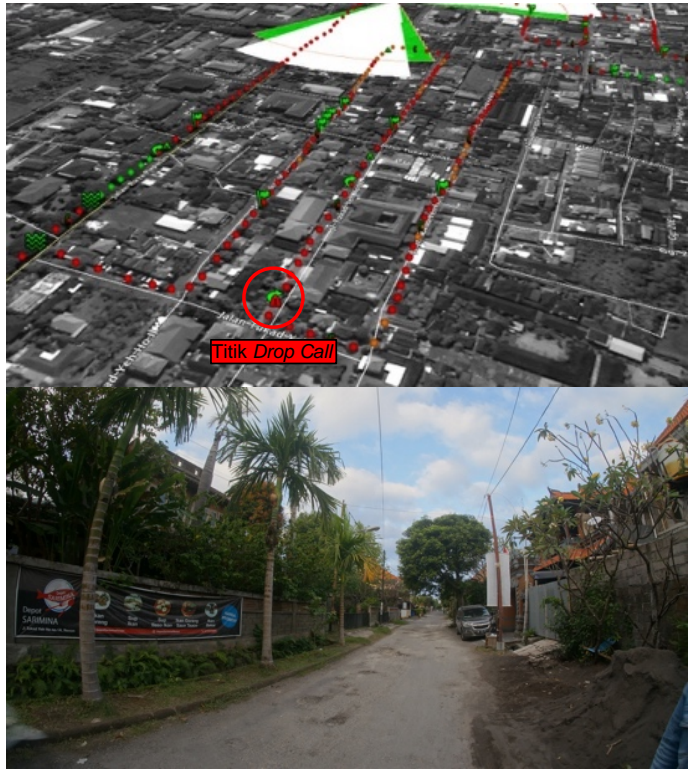

Gambar 11. Kondisi Real Titik Drop Call 7-1

Seperti yang dapat dilihat pada Gambar 11, jarak antara titik drop call dan nodeB AKABA_PL adalah $603 \mathrm{~m}$ dengan kondisi real pada titik terjadinya drop call merupakan kawasan perkantoran dan perumahan dengan rata - rata ketinggian bangunan $\pm 15 \mathrm{~m}$. Adanya obstacle ini menyebabkan margin yang didapat antara data di lapangan dengan simulasi menjadi semakin besar. Ini dapat dibuktikan dimana nilai yang didapat sebelum obstacle lebih baik $(-15 \mathrm{~dB})$ dari nilai pada titik terjadinya drop call (-19 dB). Selain itu, jika dilihat dari simulasi, nilai yang didapat sebelum titik drop call $(-13,07 \mathrm{~dB})$ juga lebih baik dibandingan nilai pada titik drop call $(-13,09$ dB). Seperti yang dapat dilihat pada Tabel 11 berikut.

Tabel 11. Hasil Perbandingan Parameter Ec/No Menggunakan Faktor Koreksi

\begin{tabular}{|c|c|c|c|}
\hline Koordinat & Keterangan & $\begin{array}{c}\text { Atoll } \\
\text { (dB) }\end{array}$ & $\begin{array}{c}\text { Pengukuran } \\
\text { (dB) }\end{array}$ \\
\hline $\begin{array}{c}8^{\circ} 40^{\prime} 26.87 " \mathrm{~S} \\
115^{\circ} 13^{\prime} 28.02 " \mathrm{E}\end{array}$ & Titik Drop Call & $-13,09$ & -19 \\
\hline $\begin{array}{c}8^{\circ} 40^{\prime} 26.86 " \mathrm{~S} \\
115^{\circ} 13^{\prime} 28.78^{\prime \prime} \mathrm{T}\end{array}$ & $\begin{array}{c}\text { Sebelum Titik } \\
\text { Drop Call }\end{array}$ & $-13,07$ & -15 \\
\hline
\end{tabular}

Dengan demikian, kondisi ekstrim ini disebabkan karena adanya obstacle berupa gedung tersebut pada kondisi real di lapangan, sehingga nilai yang didapat pada pengukuran memiliki selisih yang signifikan dibandingkan nilai pada simulasi.

\section{KESIMPULAN}

Dari analisa hasil drive test ditemukan 10 kasus drop call yang terjadi, yaitu missing neighbor (4), handover failure (4), 
Bad Spot (4), Coverage Problem (2) dan Overshoot (2).

Dari hasil simulasi Atoll, nilai rata rata yang didapat pada daerah penelitian untuk parameter RSCP adalah $-85,87 \mathrm{dBm}$ dengan total luas cakupan 2,39 $\mathrm{km}^{2}$ (Baik). Sedangkan nilai rata - rata parameter Ec/No yang didapat adalah $-23,56 \mathrm{dBm}$ dengan total luas cakupan $55,54 \mathrm{~km}^{2}$ (Sangat Buruk).

Dari beberapa kondisi ekstrim yang telah di analisa, penyebab terjadinya selisih nilai yang signifikan antara pengukuran di lapangan dengan simulasi disebabkan karena adanya obstacle berupa bangunan gedung.

\section{DAFTAR PUSTAKA}

[1] Prihartini Diyah. Analisis Drop Call Pada Jaringan 3G Indosat (Study Kasus BTS 3G BPK). Skripsi. Jakarta: Universitas Indonesia; 2009

[2] Putri Hasanah, Damayanti Tri Nopiani, Penanganan Block Call dan Drop Call Pada Jaringan UMTS Berdasarkan Pengukuran Parameter Accessibility, Coverage dan Quality, Jurnal Elektro dan Telekomunikasi Terapan, 2016; Vol.3 No.1; 239-248.

[3] Anqiang, Jiao. W-Handover and Call Drop Problem Optimization Guide. Huawei Technologies Co., Ltd. 2006

[4] Panggabean Donny, Analisis Drop Call Pada Jaringan 3G Pada Beberapa Base Station di Kota Medan, Jurnal Singuda Ensikom, 2015; Vol.10 No.27; 77-81.

[5] http://www.gyokovsolutions.com/manu als/gnettrackpro_manual.php, diakses tanggal 21 Desember 2018.

[6] Yanuari, R., Sudiarta, P.K., Gunantara, N., Analisa Kualitas Sinyal Jaringan GSM Pada Menara Rooftop Dengan Membandingkan Aplikasi Metode Drive Test Antara Tems Investigation 8.0.3 Dengan G-NetTrack Pro, E-Journal Spektrum, 2015; Vol.2 No.4; 39-45. 